\title{
Isolation of biologically active peptides from the venom of Japanese carpenter bee, Xylocopa appendiculata
}

\author{
Hiroko Kawakami ${ }^{1}$, Shin G. Goto ${ }^{2}$, Kazuya Murata ${ }^{3}$, Hideaki Matsuda ${ }^{3}$, Yasushi Shigeri ${ }^{4}$, Tomohiro Imura $^{5}$, \\ Hidetoshi Inagaki ${ }^{6}$ and Tetsuro Shinada ${ }^{1 *}$
}

\begin{abstract}
Background: Mass spectrometry-guided venom peptide profiling is a powerful tool to explore novel substances from venomous animals in a highly sensitive manner. In this study, this peptide profiling approach is successfully applied to explore the venom peptides of a Japanese solitary carpenter bee, Xylocopa appendiculata (Hymenoptera: Apoidea: Apidae: Anthophila: Xylocopinae: Xylocopini). Although interesting biological effects of the crude venom of carpenter bees have been reported, the structure and biological function of the venom peptides have not been elucidated yet.
\end{abstract}

Methods: The venom peptide profiling of the crude venom of $X$. appendiculata was performed by matrix-assisted laser desorption/ionization-time of flight mass spectroscopy. The venom was purified by a reverse-phase HPLC. The purified peptides were subjected to the Edman degradation, MS/MS analysis, and/or molecular cloning methods for peptide sequencing. Biological and functional characterization was performed by circular dichroism analysis, liposome leakage assay, and antimicrobial, histamine releasing and hemolytic activity tests.

Results: Three novel peptides with $\mathrm{m} / \mathrm{z} 16508,1939.3$, and 1900.3 were isolated from the venom of $X$. appendiculata. The peptide with $\mathrm{m} / \mathrm{z} 16508$ was characterized as a secretory phospholipase $A_{2}\left(P L A_{2}\right)$ homolog in which the characteristic cysteine residues as well as the active site residues found in bee PLA $A_{2} \mathrm{~s}$ are highly conserved. Two novel peptides with $\mathrm{m} / \mathrm{z} 1939.3$ and $\mathrm{m} / \mathrm{z} 1900.3$ were named as Xac-1 and Xac-2, respectively. These peptides are found to be amphiphilic and displayed antimicrobial and hemolytic activities. The potency was almost the same as that of mastoparan isolated from the wasp venom.

Conclusion: We found three novel biologically active peptides in the venom of $X$. appendiculata and analyzed their molecular functions, and compared their sequential homology to discuss their molecular diversity. Highly sensitive mass analysis plays an important role in this study.

Keywords: Xylocopa appendiculata, Carpenter bee, Venom peptides, Solitary bee, Mass spectrometry analysis

\section{Background}

The venom of bees (Hymenoptera: Apoidea: Anthophila) such as honeybees (Hymenoptera: Apoidea: Apidae: Anthophila: Apinae: Apini) and bumblebees (Apoidea: Apidae: Anthophila: Apinae: Bombini) has attracted significant attention as rich sources of biologically active peptides $[1,2]$. Extensive isolation and biological studies on

\footnotetext{
* Correspondence: shinada@sci.osaka-cu.ac.jp

${ }^{1}$ Graduate School of Material Science, Osaka City University, 3-3-138

Sugimoto, Sumiyoshi, Osaka 558-8585, Japan

Full list of author information is available at the end of the article
}

bee venom have disclosed that it is composed of various biologically active molecules: biogenic amines, peptides and enzymes. Apamine, MCD-peptide, melittin [3], bombolitins [4], phospholipase $\mathrm{A}_{2}\left(\mathrm{PLA}_{2}\right)$, and hyaluronidase [5] are representative peptide components isolated from the venom of the honeybee Apis mellifera [6] and bumblebees. These peptides reveal a broad range of biological activities such as mast cell degranulating, antimicrobial, histamine releasing, and/or inflammatory activities, and were speculated as toxic principles to cause severe pain [1-6]. In contrast, the venom has been utilized in folk medicine to cure 
various diseases for long time. Recently, its potential has been revisited $[7,8]$.

Mass spectrometry-guided venom peptide profiling has become an indispensable tool for rapid, accurate, and highly sensitive screening of the novel venom substances [9-12]. It contribute to accelerate the elucidation of the venom substances in the molecular structure level. Recently, we have successfully applied mass spectrometryguided venom peptide profiling to explore novel venom substances of social and solitary wasps $[13,14]$. In conjunction with our continuous research program on the isolation and biological study of the Hymenoptera venom substances, we were interested in the venom of the Japanese carpenter solitary bee Xylocopa appendiculata (Hymenoptera: Apoidea: Apidae: Anthophila: Xylocopinae: Xylocopini). We considered that the target venom is a challenging sample because of the following reasons:

- the crude venom of carpenter bees showed significant biological effects such as lethal activities in a small bird and mice [15];

- the sting of Xylocopa virginica and Xylocopa vioracea seems to be as painful in humans as are honeybee stings [15];

- although the significant biological effects of the crude venom has been suggested, the biologically active peptides of the carpenter bee venom including that of $X$. appendiculata has not been isolated yet;

- it is difficult to collect $X$. appendiculata because of their solitary lives; and

- only a small amount of the venom substances is available due to the fact that the venom sac of $X$. appendiculata is smaller than those of honeybees and vespid wasps (Fig. 1).

\section{Methods}

\section{Sample preparation}

Fifteen female bees of $X$. appendiculata were collected in Osaka and Sakai, Japan. The venom sacs were dissected and homogenized with water $(50 \mu \mathrm{L})$. The venom extract was applied to MALDI-TOF MS and HPLC analyses.

\section{MALDI-TOF MS and MS/MS analysis}

Matrix-assisted laser desorption/ionization-time of flight mass spectroscopy (MALDI-TOF MS) and tandem mass spectrometry (MS/MS) analysis was performed by UltraFlex speed (Bruker Daltonics, Germany). MS and MS/MS analyses (Additional files 1 and 2) were performed in the linear positive ion mode and reflector positive mode, respectively. $\alpha$-Cyano-4-hydroxycinnamic acid (CHCA), trifluoroacetic acid (TFA) and all other reagents were purchased from Wako Pure Chemical Industries, Ltd. (Osaka, Japan) or Nacalai Tesque (Kyoto, Japan). The matrix solution was prepared as follows. CHCA was dissolved in $3: 7$ acetonitrile $/ \mathrm{H}_{2} \mathrm{O}(0.1 \%$ TFA) to obtain saturated matrix solution. The crude venom or peptide sample were mixed with the matrix solution on a plate, dried for $5 \mathrm{~min}$ at ambient temperature, and provided for the mass analysis. Molecular mass and peptide sequencing were analyzed using the FlexAnalysis 3.4 software and BioTools 3.2 (Bruker Daltonics, Germany). The monoisotopic molecular mass was estimated in a range of $\mathrm{m} / \mathrm{z}$ $1000 \sim 5000$ for short peptides or $\mathrm{m} / z 5000 \sim 20,000$ for $\mathrm{PLA}_{2}$.

High performance liquid chromatography (HPLC) analysis HPLC analysis and purification of the crude venom was performed by Shimadzu's Prominence system (Japan). Chromatographic conditions for analysis were as follows:

- Column: COSMOSIL 5C18-AR-300, $4.6 \mathrm{~mm} \times$ $150 \mathrm{~mm}$ (Nacalai Tesque).

- Eluent: (I) $\mathrm{CH}_{3} \mathrm{CN}$ containing 0.1\% TFA and (II) $\mathrm{H}_{2} \mathrm{O}$ containing $0.1 \%$ TFA.

- Elution: linear gradient from (I):(II) $=0.1: 99.9$ to 60:40.

- Flow rate: $1.0 \mathrm{~mL} / \mathrm{min}$ for $45 \mathrm{~min}$.

- Detection: UV $210 \mathrm{~nm}$.

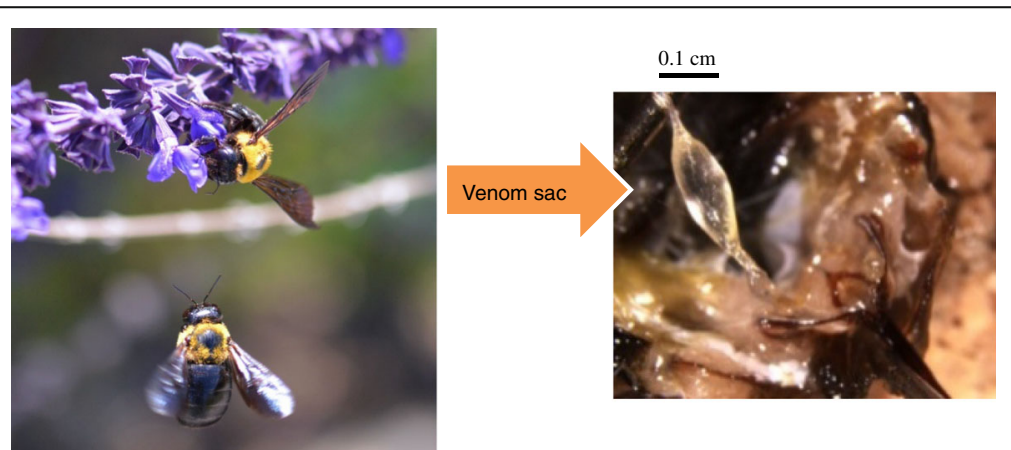

Fig. 1 Xylocopa appendiculate and its venom sac. The adults are approximately 20-25 mm in length, The image of Xylocopa appendiculate is kindly provided by Professor Hideharu Numata (Graduate School of Science, Kyoto University) 
Whereas the conditions for purification were:

- Column: COSMOSIL Protein-R, $4.6 \mathrm{~mm} \times 250 \mathrm{~mm}$ (Nacalai Tesque).

- Eluent: (I) $\mathrm{CH}_{3} \mathrm{CN}$ containing $0.1 \%$ TFA and (II) $\mathrm{H}_{2} \mathrm{O}$ containing $0.1 \%$ TFA.

- Elution: linear gradient from (I):(II) $=0.1: 99.9$ to 60:40.

- Flow rate: $1.0 \mathrm{~mL} / \mathrm{min}$ for $45 \mathrm{~min}$.

- Detection: UV $210 \mathrm{~nm}$.

\section{Peptide sequence analysis and synthesis}

The purified venom peptides were sequenced by automated Edman degradation using ABI model 477A (Applied Biosystems, USA). Peptides were synthesized by Fmoc chemistry using a Shimadzu PSSM-8 automated peptide synthesizer (Shimadzu, Japan), and purified by reverse-phase HPLC. The identity and purity of the peptides were confirmed by MALDI-TOF MS. The synthetic Xac-1 and Xac-2 were employed for circular dichroism (CD) analysis, liposome leakage assay, antimicrobial and hemolytic activity tests.

\section{Database search}

Peptide database search of the venom peptides was implemented by using NCBI database (http://www.ncbi.nlm.nih.gov/) and Hymenoptera Genome Database (http:// hymenopteragenome.org/).

\section{Circular dichroism (CD) analysis}

$\mathrm{CD}$ analysis was performed by a spectropolarimeter (J720 W; JASCO) at room temperature. Spectra were obtained at wavelength $190-260 \mathrm{~nm}$. Four scans were accumulated for each sample at a scan rate of $20 \mathrm{~nm} / \mathrm{min}$. The synthetic peptides were measured at concentration of $0.2 \mathrm{mM}$ in $\mathrm{H}_{2} \mathrm{O}$ and $50 \%(\mathrm{v} / \mathrm{v})$ trifluoroethanol (TFE)/ $\mathrm{H}_{2} \mathrm{O}$.

\section{Liposome leakage experiments}

Liposomes were prepared from lecithin from egg yolk (phosphatidylcholine approx. 70\%; Nacalai Tesque). The lecithin $(28 \mathrm{mg})$ was dissolved in chloroform $(5 \mathrm{~mL})$. The solution was concentrated in vacuo and maintained under the reduced pressure for $10 \mathrm{~h}$ to remove the solvent. The dried lecithin was hydrated in $4 \mathrm{~mL}$ of $70 \mathrm{mM}$ calcein (Sigma-Aldrich) in aqueous $\mathrm{NaOH}$ (pH 7.5). After sonication for $10 \mathrm{~min}$, the vesicles were passed through a column of Sephadex ${ }^{\text {TM }}$ G-50 (GE Healthcare) in $\mathrm{H}_{2} \mathrm{O}$ to remove free calcein. The first $5 \mathrm{~mL}$ of eluent was collected as calcein-encapsulated vesicles. Water $(0.8 \mathrm{~mL})$ was added to the liposome suspension $(0.2 \mathrm{~mL})$ in a cuvette. After $10 \mathrm{~min}, 0.5-20 \mu \mathrm{L}$ of $10 \mathrm{mM}$ solution of mastoparan (Peptide Institute, Inc., Japan) or Xac-1 was added to the cuvette. Fluorescence intensity of calcein was measured by Hitachi P-4500 fluorometer (excitation wavelength of $460 \mathrm{~nm}$ and emission wavelength of $530 \mathrm{~nm}$ ). A 1\% (v/v) solution of Triton X-100 was used as a positive control to obtain maximum fluorescent value at 100\% leakage of calcein.

\section{Molecular cloning}

RNA was extracted from the venom gland and the venom sac by Trizol reagent (Life Technologies, USA). cDNA was synthesized with oligo(dT) ${ }_{12-18}$ primer and M-MLV reverse transcriptase (Life Technologies). Degenerate primers were designed on the basis of the nucleotide sequences of $\mathrm{PLA}_{2}$ genes of several Hymenopteran species. PCR was performed with the cDNA by using Xc2 (5'AAY GGI AAY GTN GCN GAR GG-3') and Xc4 (5'AVR TCR AAC CAY TGR TA-3') primers, and subsequently the nested PCR was performed with the first PCR product as a template by using Xc2 and Xc3 (5'-GCN GAR GGI CCN GAR GAY-3') primers.

PCR products were cloned into plasmids using pGEM-T Easy Vector System (Promega, USA). Plasmids were purified with Wizard Plus SV Minipreps DNA Purification System (Promega) and sequenced on an ABI PRISM 310 Genetic Analyzer (Life Technologies) or 3130 Genetic Analyzer (Life Technologies) with BigDye Terminator v3.1 Cycle Sequence kit (Life Technologies). To obtain complete sequences of PLA ${ }_{2}$ CDNA, 3' - and 5'-RACEs (rapid amplification of cDNA ends) were performed using a SMART RACE cDNA Amplification kit (Clontech, USA) according to the supplier's instructions. F3 (5'-CGG CGC CGT AAG GTT CAC GTA CTT C) and R1 (5'-GCT GAA GGA GAC CGA CGC CTG TTG T-3') primers were used for 3' - and 5' RACEs, respectively. The obtained PCR products were also cloned into a vector, and sequenced as described above.

\section{Antimicrobial activity}

According to the procedure $[16,17]$, antimicrobial activities of Xac-1 and Xac-2 were evaluated using Escherichia coli (NBRC14237) and Micrococcus luteus (NBRC 12708) as a gram-negative bacterium, Stapylococcus aureus (NBRC12708) as a gram-positive bacterium, and the yeast Saccharomyces cerevisiae (NBCR 10217). To compare the potency, MIC values of mastoparan were evaluated. Bacteria were grown in $2 \mathrm{~mL}$ Trypticase soy broth, and yeasts in Sabouraud dextrose broth for $16 \mathrm{~h}$ with shaking at $200 \mathrm{rpm}$ as a pre-culture. Subsequently, $0.1 \mathrm{~mL}$ pre-culture medium was inoculated into $2 \mathrm{~mL}$ of fresh medium. It was cultivated for $2-3 \mathrm{~h}$ until $\mathrm{A}_{600}=$ 0.5 . The cultivated medium was diluted with PBS solution. The diluted microbial broth $(100 \mu \mathrm{L})$ was mixed with peptide solutions $(11 \mu \mathrm{L})$ in 96 -well plates and incubated for $3 \mathrm{~h}$. After $3 \mathrm{~h}$ incubation, two times concentrated medium were added and 96-well plates were reincubated for $16 \mathrm{~h}$. Microbial growth was measured by Spectra MAX 190 microplate reader at $\mathrm{A}_{600}$. 


\section{Hemolytic activity}

According to the procedure described by Shigeri et al. [12], hemolytic activities of Xac-1 and Xac-2 were tested. Heparinized rat whole blood from Wistar rats (male, 6 weeks old) was washed twice in $\mathrm{NaCl} / \mathrm{Pi}$ $\left(100 \mathrm{mM} \mathrm{NaCl}, 7.5 \mathrm{mM} \mathrm{Na} \mathrm{HPO}_{4}\right.$ and $2.5 \mathrm{mM}$ $\mathrm{NaH}_{2} \mathrm{PO}_{4}$ ) by centrifugation at $900 \mathrm{~g}$ and suspended in $\mathrm{NaCl} / \mathrm{Pi}$ to a concentration of $0.5 \%(\mathrm{v} / \mathrm{v}) \cdot \mathrm{NaCl} / \mathrm{Pi}$ and $\mathrm{NaCl} / \mathrm{Pi}$ containing $0.2 \%$ Triton $\mathrm{X}-100$ were used as controls for 0 and $100 \%$ hemolysis, respectively. Xac-1 and Xac-2, as well as mastoparan and melittin were employed as comparable standards.

\section{Histamine releasing activity}

The histamine-releasing activities of Xac-1 and Xac-2, mastoparan, and melittin were determined with rat peritoneal mast cells, as previously described [17]. The histamine-releasing activity was defined as the ration of the extracellular to the total amount of histamine. Spontaneous histamine-releasing activity was $6.9 \pm 0.3 \%$.

\section{Results}

MALDI-TOF MS and HPLC analysis of the crude venom extract of $X$. appendiculata

The crude venom extract of $X$. appendiculata was subjected to MALDI-TOF MS analysis (Fig. 2a and b). The MSPP analysis in a range of $\mathrm{m} / z 1000 \sim 5000$ (Fig. 2a) indicated that peptides in a range of $\mathrm{m} / \mathrm{z}$ $1850 \sim 2200$ are the major in the venom of X. appendiculata. Characteristic ion signal at $\mathrm{m} / z 16508$ was observed in a range of $m / z 5000 \sim 20000$ (Fig. 2b). Having these profiles, the crude venom was subjected to HPLC purification with a C18-reversed phase column to provide eight major fractions (A to H) (Fig. 3). Fractions A, D, F, and G included peptides with $\mathrm{m} / \mathrm{z}$ 2066, 16508, 1939.3 and 1900.3, respectively. These molecular ions were originated from the venom because the same $\mathrm{m} / \mathrm{z}$ were found in the crude venom analysis. MS analysis of fractions B, C, E, and F showed that these are composed of a mixture of several peptides.

\section{Peptide sequence of peptides in fractions $A, D, F$, and $G$} Edman degradation of fraction $\mathrm{F}\left([\mathrm{M}+\mathrm{H}]^{+} m / z\right.$ 1939.3) provided a partial peptide sequence - GFVALLKKLPLILKHL - except for the C-terminal amino acid residue. MS/MS analysis (-L/I-L/I-L/I-K-H-L/I-H) indicated that the amino acid residue at the $\mathrm{C}$-terminal was histidine (Additional file 1). Although the sequence was putatively assigned as GFVALLKKLPLILKHLH, the theoretical monoisotopic mass number of GFVALLKKLPLILKHLH$\mathrm{OH}$ (1939.25) differed from the observed mass number (1938.2). These results suggest a possibility of the C- terminal amidation. To prove this possibility, GFVALLKKLPLILKHLH-NH $\mathrm{N}_{2}$ was prepared and subjected to HPLC analysis to compare retention time. Retention times of the synthetic and naturally occurring peptide were identical. As a result, the peptide of fraction $F$ was determined to be GFVALLKKLPLILKHLH-NH$H_{2}$. In a similar manner, the peptide of fraction $G$ was identified as GFVALLKKLPLILKHLP-NH $\mathrm{N}_{2}$ (Additional file 2).

These peptide sequences were not registered in the NCBI database (http://www.ncbi.nlm.nih.gov/) and Hymenoptera Genome Database (http://hymenopteragenome.org/). Thus, we named these novel peptides Xac-1 (GFVALLKKLPLILKHLH-NH ${ }_{2}, \quad[\mathrm{M}+\mathrm{H}]^{+} \mathrm{m} / z$ 1939.3) and Xac-2 (GFVALLKKLPLILKHLP-NH ${ }_{2}$, [M $+\mathrm{H}]^{+} m / z$ 1900.3). Edman degradation analysis of fraction A $\left([\mathrm{M}+\mathrm{H}]^{+} m / z\right.$ 2066) was not successfully done, though the reason was unclear. It is speculated that it might be a cyclic peptide with an S-S bond that prevent the Edman analysis. Further sequence analysis is ongoing.

Edman degradation of the peptide of fraction $\mathrm{D}$ provided a partial sequence: IIFVG TKWCG NGNVA EGPED LGSLK E-. Sequence similarity searches showed that the partial sequence conserved a $70 \%$ identity with those of $\mathrm{PLA}_{2} \mathrm{~S}$ isolated from the bumblebee Bombus hypocrite (Apidae: Apinae: Bombini) and the social honeybee A. mellifera [18]. We hypothesized that this peptide would be a $\mathrm{PLA}_{2}$ homolog and attempted molecular cloning and RACE to elucidate the full nucleotide sequence encoding this peptide (Fig. 4). The resulting sequence (DDBJ/ GenBank/EMBL accession no. AB731659) was compared with those of $\mathrm{PLA}_{2} \mathrm{~S}$ isolated from bee venom, indicating that the $\mathrm{PLA}_{2}$ homolog conserves characteristic amino acid residues associated with the catalytic activity of $\mathrm{PLA}_{2} \mathrm{~S}$ of honey and bumblebees [18, 19]. It is speculated that the $\mathrm{PLA}_{2}$ of $X$. appendiculata is a product of a post-translational modification due to the fact that the molecular mass number of fraction $\mathrm{D}\left([\mathrm{M}+\mathrm{H}]^{+} m / z\right.$ 16508) was not identical to that of the peptide estimated by the molecular cloning.

\section{Physicochemical properties of Xac-1 and Xac-2: helical wheel projection analysis, CD spectroscopy analysis, and liposome leakage assay}

The helical wheel projection of Xac-1 and Xac-2 was made by the database program (http://www.tcdb.org/ progs/?tool=pepwheel) [20]. The results suggest that these peptides possess amphiphilic helical structures in which positively charged amino acid resides, histidines and lysines are arranged on one side and hydrophilic residues on the other side (Fig. 5). To obtain an analytical proof, CD spectra of Xac-1 was 


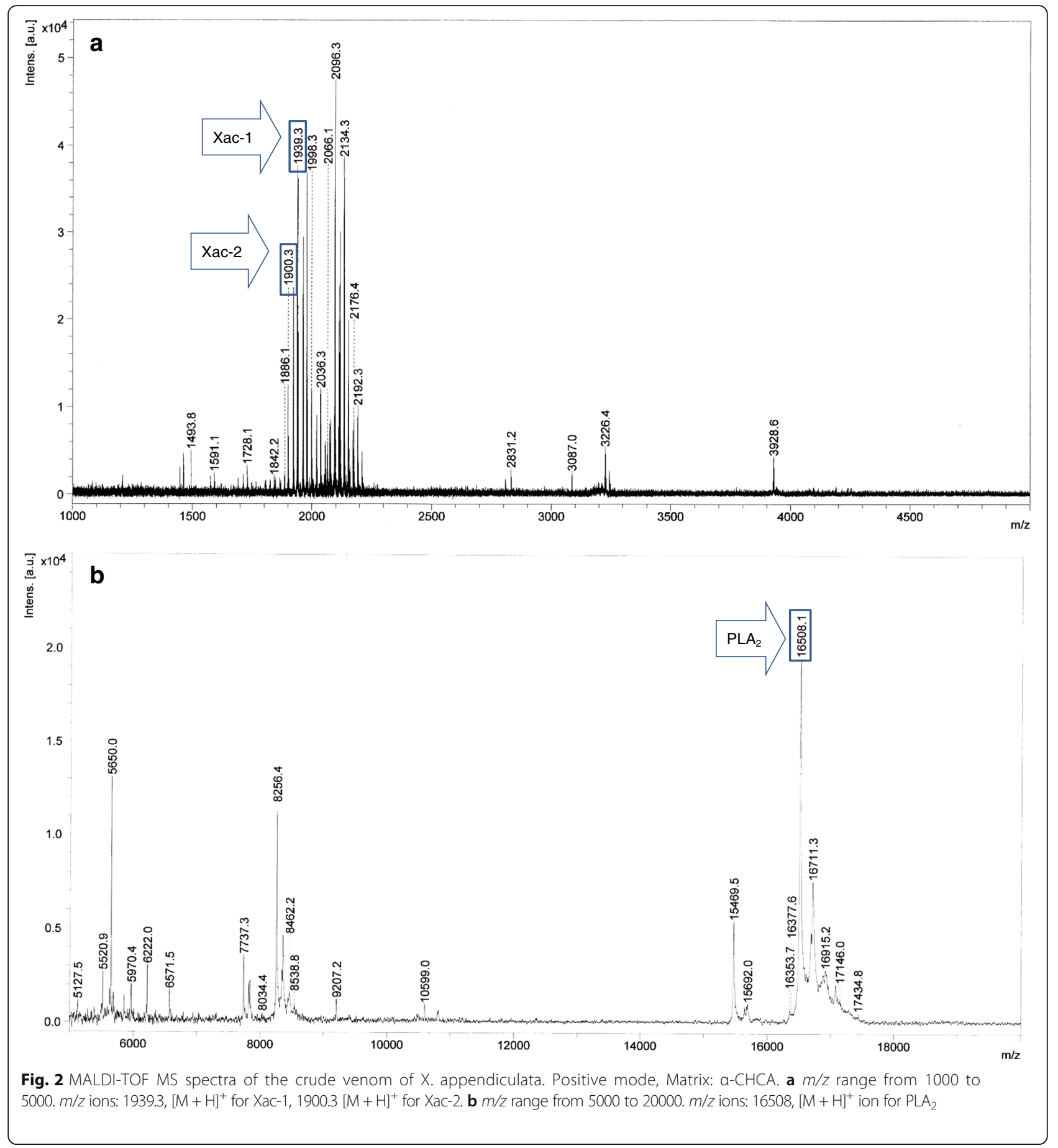

measured. Xac-1 exhibited a mostly disordered conformation in aqueous solution whereas a higher $\alpha$ helical content in 50\% TFE solution (Fig. 6). The presence of two negative dichroic bands at 208 and $222 \mathrm{~nm}$ was consistent with the preferential formation of $\alpha$-helix. Subsequently, we analyzed liposome leakage properties of Xac-1 (Fig. 7). Xac-1 revealed liposome degradation activity in which its potency was almost the same as that of mastoparan.
Biological activities of Xac-1 and Xac-2

Antimicrobial and hemolytic activities of Xac-1 and Xac-2 were examined. Mastoparan (14 amino acid amphiphilic peptides from wasp venom) was selected as a reference peptide because it is a representative amphiphilic peptide that shows antimicrobial and hemolytic activities due to its potent pore forming effects and mast cell degradation activities [7]. In addition, melittin isolated from the venom of $A$. 


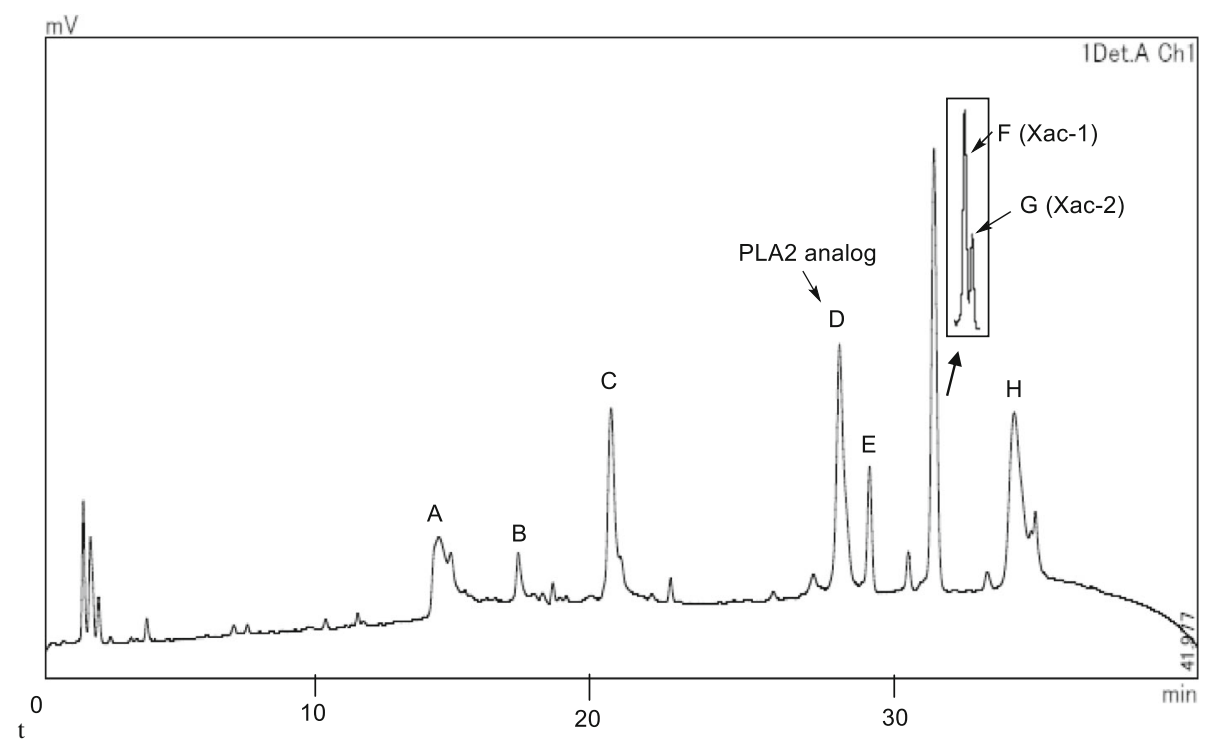

Fig. $3 \mathrm{HPLC}$ analysis of the crude venom. Column: COSMOSIL 5C18-AR-300, $4.6 \mathrm{~mm} \times 150 \mathrm{~mm}$ (Nacalai Tesque). Eluent: (I) $\mathrm{CH}_{3} \mathrm{CN}_{\mathrm{C}}$ containing $0.1 \%$ TFA and (II) $\mathrm{H}_{2} \mathrm{O}$ containing 0.1\% TFA. Elution: linear gradient from (I):(II)= 0.1:99.9 to 60:40. Flow rate, $1.0 \mathrm{~mL} / \mathrm{min}$ for $45 \mathrm{~min}$. Detection: UV $210 \mathrm{~nm}$. Purity of each fraction was monitored by MALDI-TOF MS. A: $\mathrm{m} / \mathrm{z} 2066 ; B$ and C: mixture ( $\mathrm{m} / \mathrm{z} 2066$ was mainly detected); D: $\mathrm{m} / \mathrm{z} 16508$ (PLA 2 homolog); E: mixture; F: m/z 1939.3 (Xac-1); G: m/z 1900.3 (Xac-2); H: mixture

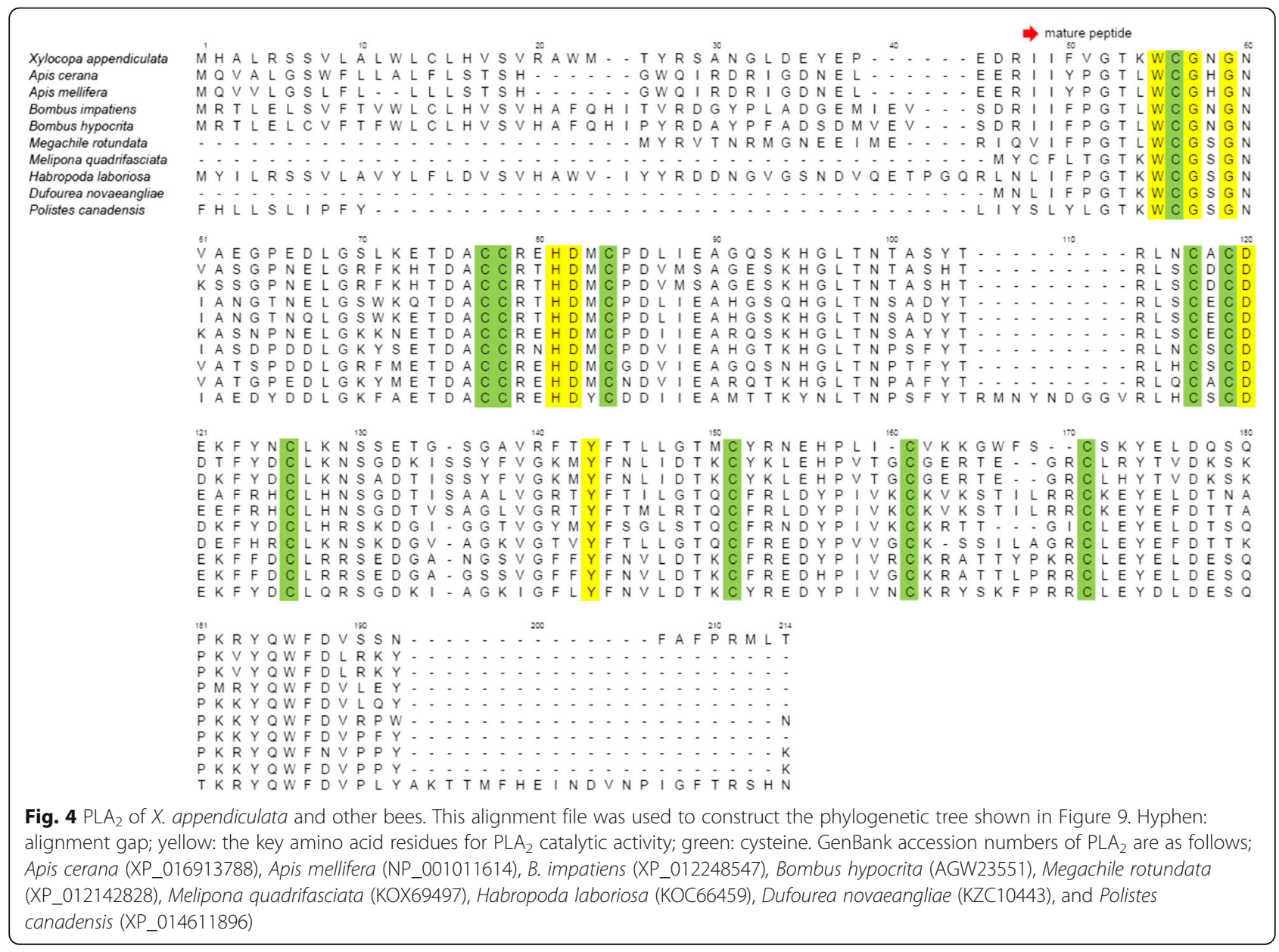



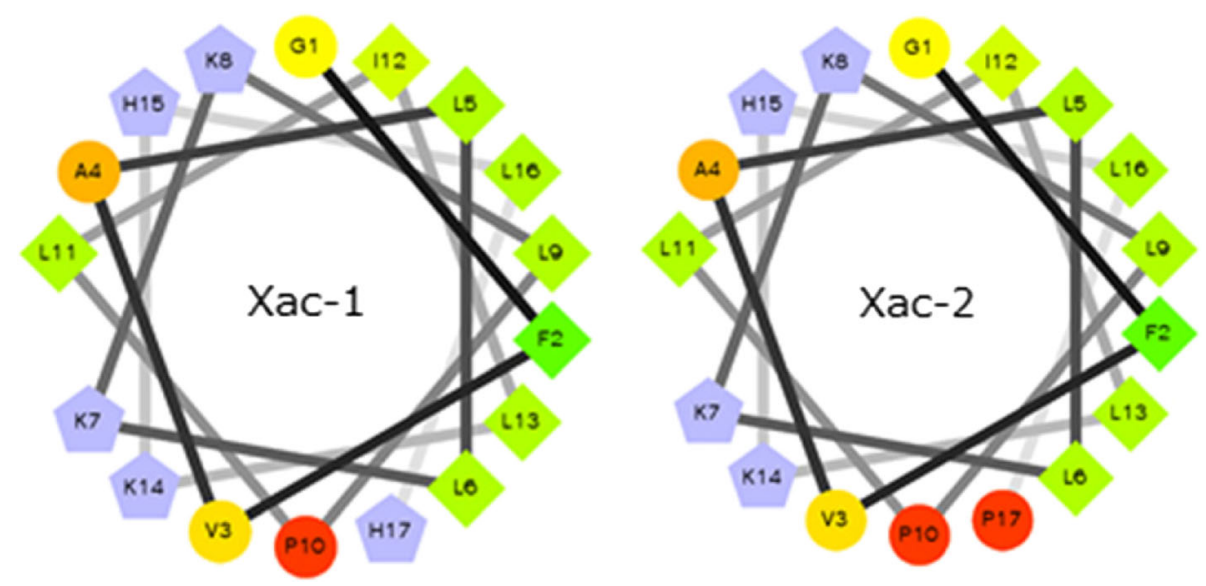

Fig. 5 Helical wheel projection of Xac-1 and Xac-2. Blue: basic amino acids, others: neutral amino acids

mellifera was used as a reference to compare hemolytic activity [3]. These results are summarized in Table 1. Xac-1 exhibited growth inhibitory effects against E. coli, S. aureus, M. luteus, and S. cerevisiae with $\mathrm{MIC}$ values in a range from 1.57 to $6.25 \mu \mathrm{M}$. The potency is similar to that of mastoparan. Xac-2 showed almost the same or slightly less potency as Xac- 1 on the antimicrobial activities using $M$. luteus and $S$. cerevisiae. Xac-1 and Xac-2 exerted hemolytic activities (37.5 and $23.5 \%$ at $100 \mu \mathrm{M})$, respectively. These data were compared with those of mastoparan $(40.6 \%$ at $100 \mu \mathrm{M})$ and melittin $(91.8 \%$ at $10 \mu \mathrm{M})$. These results indicated that the potencies of Xac-1 and Xac- 2 were close to that of mastoparan, whereas these potencies were much weaker than that of melittin. Bioactive peptides isolated from ant, bee, and wasp have been shown to activate the release of histamines from rat peritoneal mast cells [17]. Both Xac1 and Xac- 2 caused a significant and dose-dependent histamine release. At a concentration of $10 \mu \mathrm{M}$, Xac1 and Xac-2 displayed 58.0 and $53.0 \%$ of histaminereleasing activities, respectively. These activities

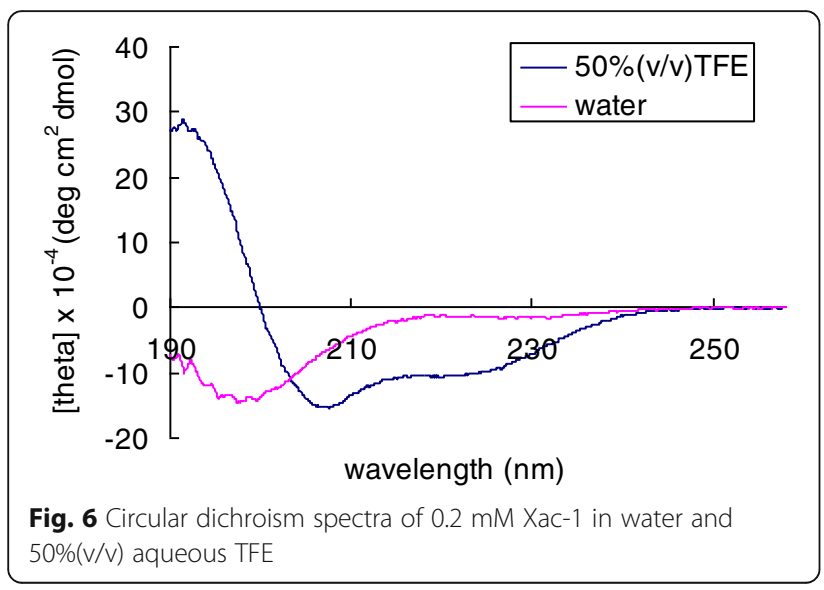

comparable to mastoparan (57.6\%), but less effective than melittin $(84.8 \%)$.

\section{Discussion}

Bees are classified into seven families including more than 16,000 described species [21]. Female bees use their venom for defense when they are exposed to dangers and predators. Bee stings are known to be painful. In contrast to the unpleasant effects of bee toxins in humans, its venom has been utilized as a remedy for centuries and recently has attracted much attention as a promising alternative and preventive medicine for the treatment of arthritis, rheumatism, pain, and cancer, etc. [8, 22]. Although many biologically active peptides and enzymes have been isolated from the venom of social honeybees such as $A$. mellifera and a eusocial bumblebee (Megabombus pennsylvanicus), the structure elucidation of the venom substances of carpenter bees has not been well examined except for the Nakajima's study [23] on the analysis of biogenic amines in the venom of $X$. appendiculate. It revealed that histamine, putrescine and spermidine were detected as major biogenic amines in the venom. Piek [15] predicted that the presence of melittin-like peptides in the venom of $X$. violacea by comparison with biological activities of the crude venom of $X$. violacea, A. mellifera, and Bombus terrestris. To the best of our knowledge, isolation of the peptide substances in the carpenter venom has not been elucidated yet.

In this study, we found two novel amphiphilic peptides, Xac-1 and Xac-2, and a new PLA 2 homolog in the venom of $X$. appendiculata for the first time. Our results corroborate that by Nakajima et al. [23] by clearly showing that the venom of $X$. appendiculata is a cocktail of biogenic amines, amphiphilic peptides, $\mathrm{PLA}_{2}$ and the molecular constitution 


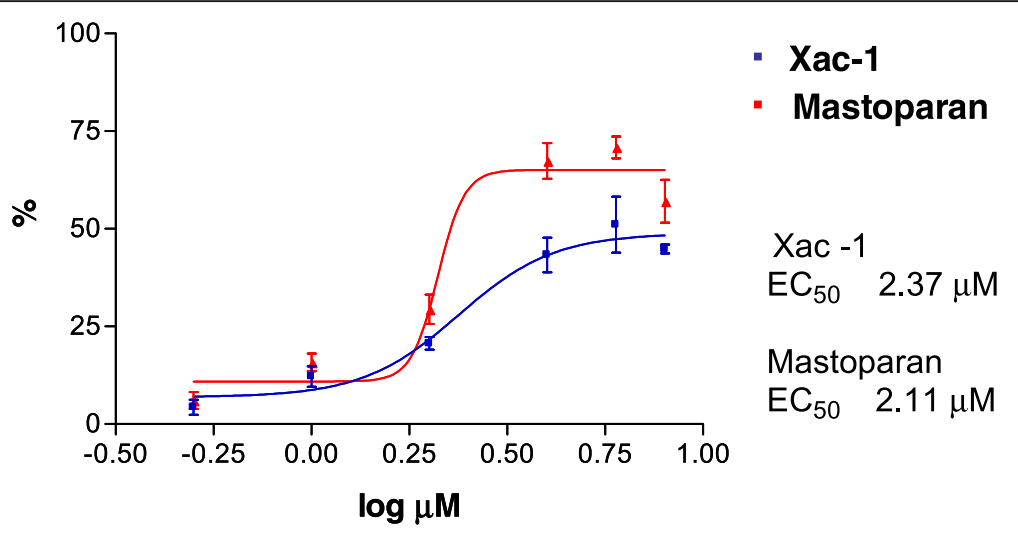

Fig. 7 Liposome leakage assay of Xac-1 (blue) and mastoparan (red)

resembles those of honeybees and bumblebees. It is supposed that Xac-1 and Xac-2 would be a principle of the melittin-like peptide proposed by Piek [15] since biological activities of Xac-1 and Xac-2 resemble those of melittin.

Recently, the research interests for venoms has reached other families of solitary and eusocial bees (Fig. 8). These studies have unveiled the distribution of amphiphilic and biologically active peptides such as melectin from Mellecta albifrons (Apoidea: Melectini) [24], codesane from Colletes daviesanus (Colletidae) [25], osmin from Osma rufa (Megachilidae) [26], lasioglossins from Lasioglossum laticeps (Halicitidae) [27], halictines from Halictus sexcinctus (Halicitidae) [28], macropin from Macropis fulvipes (Melittidae) [29] in the bee venom. It is interesting to note that the amino acid sequences of Xac-1 and Xac-2 are similar to those of melectin and osmin isolated from the long-tonged bees, but not to those of bombolitins and melittin isolated from the social bee venom, though carpenter bees, bumblebees and honeybees are closely related. These comparable analyses indicate a possibility that Xac-1, Xac-2, melectin and osmin would be derived from a prototype amphiphilic peptide of the ancestor of solitary bees. On the other hand, melittin, bombolitins, mastoparan may have separately developed during the course of the social evolution. To prove this hypothesis, further research on isolation and biological studies on the bee venom peptides are required.

$\mathrm{PLA}_{2}$ is known to be the main enzyme component of bee venom. Previously, the presence of $\mathrm{PLA}_{2}$ in the venom of Anthophora pauperata (Apidae) was proposed by biological and hematological studies [30]. To the best of our knowledge, structure analysis of the $\mathrm{PLA}_{2}$ of carpenter bees has not been examined yet. We isolated the $\mathrm{PLA}_{2}$ of $X$. appendiculata and found that it has a high sequence identity with $\mathrm{PLA}_{2}$ of related species such as bumblebees and honeybees (Fig. 4) [31]. We also analyzed the molecular evolution of bee $\mathrm{PLA}_{2} \mathrm{~S}$ using database sets (Fig. 9) [32, 33]. Interestingly, $\mathrm{PLA}_{2}$ evolution tree did not match with the bee phylogeny that is well-established by large dataset though the characteristic amino acid residues of the $\mathrm{PLA}_{2}$ family of honeybees and bumblebees are highly conserved in the $\mathrm{PLA}_{2}$ of $X$. appendiculata. Our analysis would contribute to discuss the evolution patterns of $\mathrm{PLA}_{2} \mathrm{~S}$ of the bee venoms.

\section{Conclusion}

We have analyzed the venom components of the solitary bee $X$. appendiculata and isolated novel amphiphilic peptides, Xac-1 and Xac-2, and a PLA 2

Table 1 Biological activities of Xac-1, Xac-2, mastoparan, and melittin

\begin{tabular}{|c|c|c|c|c|c|c|}
\hline & \multicolumn{4}{|c|}{ Antimicrobial activity (MIC) } & \multirow{2}{*}{$\begin{array}{l}\text { Hemolytic } \\
\text { activity at } \\
100 \mu \mathrm{M}\end{array}$} & \multirow{2}{*}{$\begin{array}{l}\text { Histamine } \\
\text { releasing } \\
\text { activity at } \\
10 \mu \mathrm{M}\end{array}$} \\
\hline & E. coli (NBRC 14237) & S. aureus (NBRC 12732) & M. luteus (NBRC 12708) & S. cerevisiae (NBRC 10217) & & \\
\hline Xac 1 & $3.12 \mu \mathrm{M}$ & $1.57 \mu \mathrm{M}$ & $3.12 \mu \mathrm{M}$ & $6.25 \mu \mathrm{M}$ & $37.5 \pm 1.9 \%$ & $58.0 \pm 1.7 \%$ \\
\hline Xac 2 & $3.12 \mu \mathrm{M}$ & $3.12 \mu \mathrm{M}$ & $6.25 \mu \mathrm{M}$ & $25.0 \mu \mathrm{M}$ & $23.5 \pm 1.3 \%$ & $53.0 \pm 4.3 \%$ \\
\hline Mastoparan & $6.25 \mu \mathrm{M}$ & $1.57 \mu \mathrm{M}$ & $3.12 \mu \mathrm{M}$ & $6.25 \mu \mathrm{M}$ & $40.6 \pm 2.7 \%$ & $57.6 \pm 1.0 \%$ \\
\hline Melittin & - & - & - & - & $91.8 \pm 1.8 \%^{\mathrm{a}}$ & $84.8 \pm 10.1 \%$ \\
\hline
\end{tabular}

${ }^{\mathrm{a}}$ Hemolytic activities at $10 \mu \mathrm{M}$ of melittin was indicated 


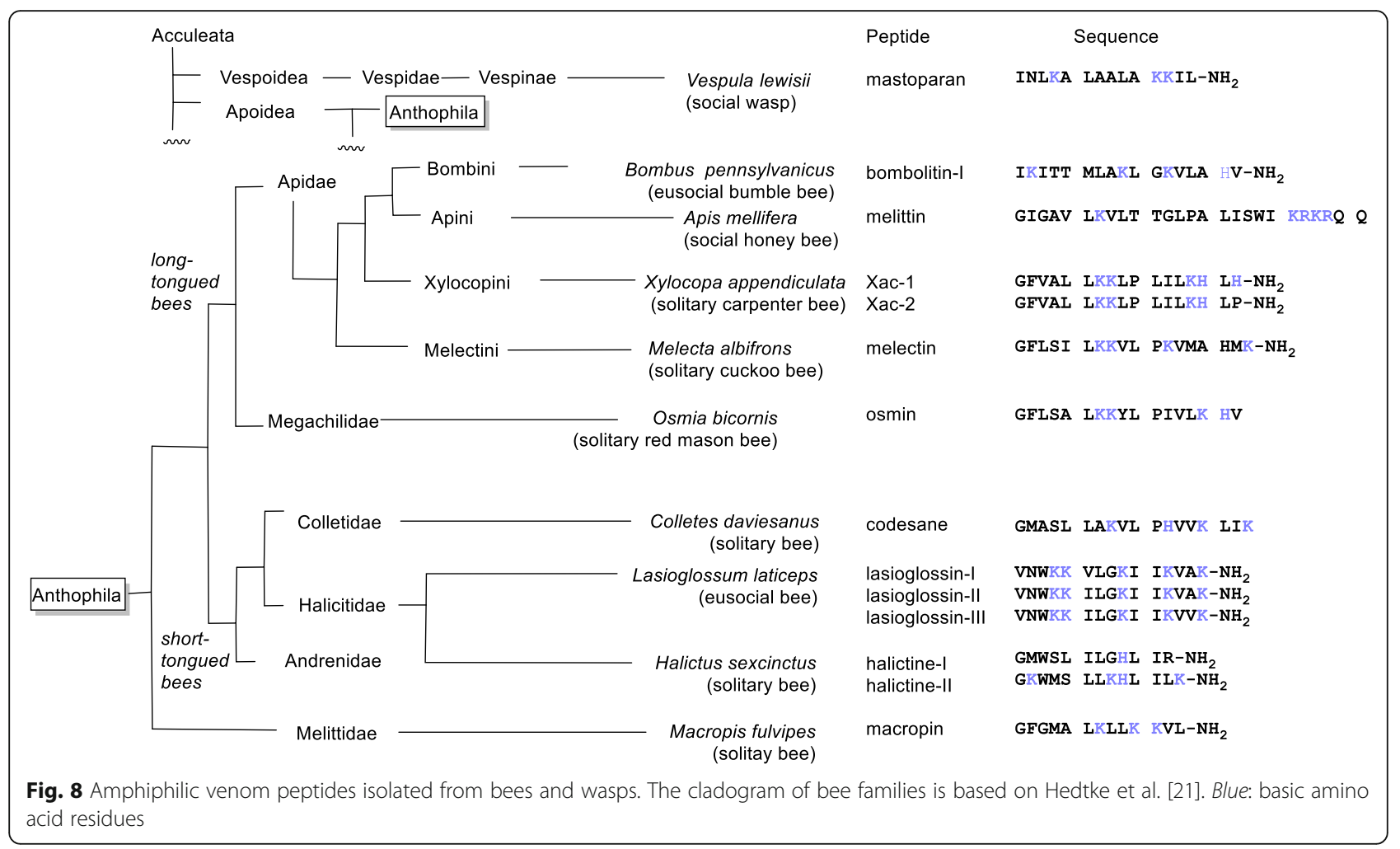

homolog. The accurate analysis and structure determination of the venom reveals that it is a cocktail of various biologically active molecules. Our study helps to understand the biological function and molecular diversity of the solitary bee venom components. Additionally, it may aid in the design of biologically active peptides based on the structures of Xac-1 and Xac-2 to develop more potent peptide analogs toward biotechnological and medical applications. a

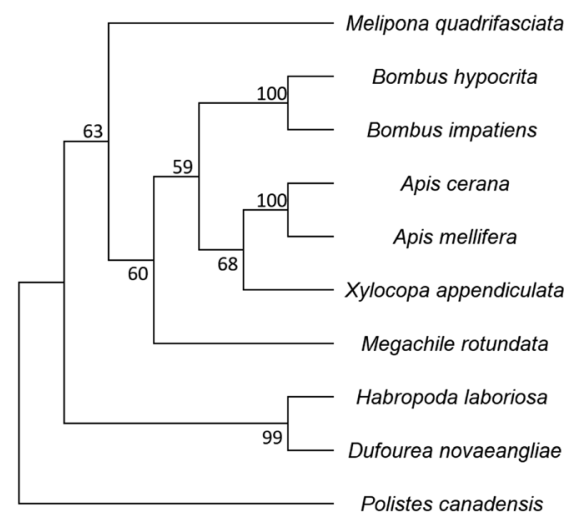

b Hymenoptera

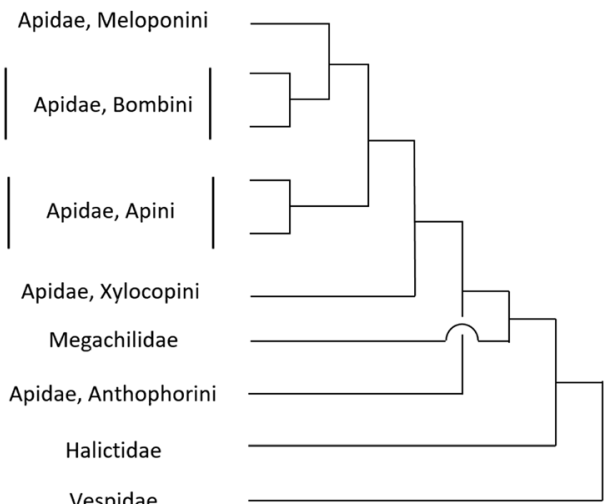

Fig. 9 Molecular Phylogenetic analysis by Maximum Likelihood method based on PLA2 amino acid sequences (a) and phylogenetic tree proposed by Hedtke et al. [21] (b). The evolutionary history was inferred by using the Maximum Likelihood method based on the Whelan And Goldman model [32]. The tree with the highest log likelihood (-1575.2225) is shown. The percentage of trees in which the associated taxa clustered together is shown next to the branches (bootstrap value). Initial tree(s) for the heuristic search were obtained automatically by applying Neighbor-Join and BioNJ algorithms to a matrix of pairwise distances estimated using a JTT model, and then selecting the topology with superior log likelihood value. The rate variation model allowed for some sites to be evolutionarily invariable ([+l], 28.9827\% sites). All positions containing gaps and missing data were eliminated. There were a total of 130 positions in the final dataset. Evolutionary analyses were conducted in MEGA7 [33] 


\section{Additional files}

Additional file 1: MS/MS analysis of Xac-1. (DOCX $175 \mathrm{~kb}$ )

Additional file 2: MS/MS analysis of Xac-2. (DOCX $157 \mathrm{~kb}$ )

\section{Abbreviations}

CD: Circular dichroism; CHCA: a-Cyano-4-hydroxycinnamic acid; HPLC: High performance liquid chromatography; MALDI-TOF MS: Matrix-assisted laser desorption/ionization-time of flight mass spectroscopy; MS/MS: Tandem mass spectrometry; PLA 2 : Phospholipase $A_{2}$; TFA: Trifluoroacetic acid

\section{Acknowledgments}

YS thanks to the support from JSPS KAKENHI, grant number 15 K01814.

\section{Funding}

This work was supported by JSPS KAKENHI, grant number 15 K01814.

\section{Authors' contributions}

TS designed this work, prepared this manuscript and sampling of $X$. appendiculata. HK contributed to sampling of X. appendiculata, MALDI-TOF MS analysis, HPLC analysis, and liposome leakage assay. SGG prepared CDNA for PLA 2 . KM and HM performed sequential analysis of Xac-1, Xac-2, and $\mathrm{PLA}_{2}$. YS synthesized Xac-1 and Xac-2, and designed biological assays. TI and $\mathrm{HI}$ evaluated biological activities of Xac-1 and Xac-2. All authors read and approved the final manuscript

\section{Competing interests}

The authors declare that they have no competing interests.

\section{Consent for publication}

Not applicable.

\section{Ethics approval and consent to participate}

Experiments procedures for hemolytic activity tests were in accordance with the guidelines of the Care and use of Laboratory Animals of AIST.

\section{Publisher's Note}

Springer Nature remains neutral with regard to jurisdictional claims in published maps and institutional affiliations.

\section{Author details \\ ${ }^{1}$ Graduate School of Material Science, Osaka City University, 3-3-138 Sugimoto, Sumiyoshi, Osaka 558-8585, Japan. ${ }^{2}$ Graduate School of Science, Department of Biology \& Geosciences, Osaka City University, 3-3-138 Sugimoto, Sumiyoshi, Osaka 558-8585, Japan. ${ }^{3}$ Faculty of Pharmacy, Kindai University, 3-4-1 Kowakae, Higashiosaka, Osaka 577-8502, Japan. ${ }^{4}$ Health Research Institute, National Institute of Advanced Industrial Science and Technology (AIST), Osaka, Japan. ${ }^{5}$ Research Institute for Chemical Process Technology, National Institute of Advanced Industrial Science and Technology (AIST), Ibaraki, Japan. ${ }^{6}$ Biomedical Research Institute, National Institute of Advanced Industrial Science and Technology (AIST), Ibaraki, Japan.}

\section{Received: 27 January 2017 Accepted: 9 May 2017}

Published online: 23 May 2017

\section{References}

1. Palma MS. Hymenoptera Insect Peptides. Kastin AJ, editor. In: Handbook of Biologically Active Peptides. Elsevier; 2013. p. 416-22.http://www. sciencedirect.com/science/book/9780123694423.

2. Piek T. Venoms of the Hymenoptera, biochemical, pharmacological and behavioral aspects. London: Academic; 1986. https://www.elsevier.com/ books/venoms-of-the-hymenoptera/piek/978-0-12-554770-3.

3. Chen J, Guan SM, Sun W, Fu H. Melittin, the major pain-producing substance of bee venom. Neurosci Bull. 2016;32(3):265-72.

4. Argiolas A, Pisano JJ. Bombolitins, a new class of mast cell degranulating peptides from the venom of the bumblebee Megabombus pennsylvanicus. J Biol Chem. 1985;260(3):1437-44.
5. Lee $\mathrm{G}$, Bae H. Bee venom phospholipase A2: yesterday's enemy becomes today's friend. Toxins (Basel). 2016;8(2):48.

6. de Lima PR, Brochetto-Braga MR. Hymenoptera venom review focusing on Apis mellifera. J Venom Anim Toxins Incl Trop Dis. 2003; 9(2):1-24. http://www.scielo.br/scielo.php?script=sci_arttext\&pid= S1678-91992003000200002.

7. Moreno M, Giralt E. Three valuable peptides from bee and wasp venoms for therapeutic and biotechnological use: melittin, apamin and mastoparan. Toxins (Basel). 2015;7(4):1126-50.

8. Son DJ, Lee JW, Lee YH, Song HS, Lee CK, Hong JT. Therapeutic application of anti-arthritis, pain-releasing, and anti-cancer effects of bee venom and its constituent compounds. Pharmacol Ther. 2007;115(2):246-70.

9. Escoubas P. Mass spectrometry in toxinology: A 21st-century technology for the study of biopolymers from venoms. Toxicon. 2006;47(6):609-13.

10. Favreau P, Menin L, Michalet S, Perret F, Cheneval O, Stöcklin M, et al. Mass spectrometry strategies for venom mapping and peptide sequencing from crude venoms: case applications with single arthropod specimen. Toxicon. 2006;47(6):676-87.

11. Nakajima T, Naoki H, Corzo G, Li D, Hisada M, Escoubas P, et al. A trial of mass spectrometric characterization of femto-molar amount from subtropical islands. J Toxicol. 2003;22(4):509-20.

12. Shigeri $Y$, Yasuda A, Hagihara $Y$, Nishi K, Watanabe K, Imura T, et al. Identification of novel peptides from amphibian (Xenopus tropicalis) skin by direct tissue MALDI-MS analysis. FEBS J. 2015;282(1):102-13.

13. Murata K, Shinada T, Ohfune Y, Hisada M, Yasuda A, Naoki H, et al. Novel mastoparan and protonectin analogs isolated from a solitary wasp, Orancistrocerus drewseni drewseni. Amino Acids. 2009;37(2):389-94.

14. Murata K, Shinada T, Ohfune Y, Hisada M, Yasuda A, Naoki H, et al. Novel biologically active peptides from the venom of Polistes rothneyi iwatai. Biol Pharm Bull. 2006;29(12):2493-7.

15. Piek T. The venom of bumble-bees and carpenter-bees. In: Piek T, editor. The Venoms of the Hymenoptera, biochemical, pharmacological and behavioral aspects. London: Academic; 1986. p. 417-24.

16. Steinberg DA, Lehrer RI. Designer assays for antimicrobial peptides. antibacterial peptide protocols. In: Shafer WM, editor. Methods in molecular biology, vol. 78. Tokowa: Humana Press; 1997. p. 169-86.

17. Inagaki H, Akagi M, Imai HT, Taylor RW, Kubo T. Molecular cloning and biological characterization of novel antimicrobial peptides, pilosulin 3 and pilosulin 4, from a species of the Australian ant genus Myrmecia. Arch Biochem Biophys. 2004;428(2):170-8.

18. Arni RK, Ward RJ. Phospholipase A2 - a structural review. Toxicon. 1996;34(8):827-41.

19. Annand RR, Kontoyianni M, Penzotti JE, Dudler T, Lybrand TP, Gelb MH. Active site of bee venom phospholipase A2: the role of histidine-34, aspartate-64 and tyrosine-87. Biochemistry. 1996;35(14):4591-601.

20. Transporter Classification Database. http://www.tcdb.org/progs/?tool=pepwheel. Accessed 15 May 2017.

21. Hedtke SM, Patiny S, Danforth BN. The bee tree of life: a supermatrix approach to apoid phylogeny and biogeography. BMC Evol Biol. 2013;13:138.

22. Bellik Y. Bee venom: its potential use in alternative medicine. Anti-Infective Agents. 2015;13(1):3-16.

23. Nakajima T, Yasuhara T, Yoshida N, Takemoto $Y$, Shinonaga S, Kano R, et al. The pattern analysis of biologieallyaetive amines in some Hymenopteran venoms by high performance liquid chromatography. Jap J Sanit Zool. 1983;34(2):61-71.

24. Cujová S, Bednárová L, Slaninová J, Straka J, Cerovsky V. Interaction of a novel antimicrobial peptide isolated from the venom of solitary bee Colletes daviesanus with phospholipid vesicles and Escherichia coli cells. J Pept Sci. 2014;20(11):885-95.

25. Cerovský V, Hovorka O, Cvacka J, Voburka Z, Bednárová L, Borovicková L, et al. Melectin: a novel antimicrobial peptide from the venom of the cleptoparasitic bee Melecta albifrons. Chembiochem. 2008;9(17):2815-21.

26. Stocklin R, Favreau P, Thai R, Pflugfelder J, Bulet P, Mebs D. Structural identification by mass spectrometry of a novel antimicrobial peptide from the venom of the solitary bee Osmia rufa (hymenoptera: megachilidae). Toxicon. 2010;55:20-7.

27. Cerovský V, Budesínský M, Hovorka O, Cvacka J, Voburka Z, Slaninová J, et al. Lasioglossins: three novel antimicrobial peptides from the venom of the eusocial bee Lasioglossum laticeps (Hymenoptera: Halictidae). Chembiochem. 2009;10(12):2089-99.

28. Monincová L, Budesínský M, Slaninová J, Hovorka O, Cvacka J, Voburka Z, et al. Novel antimicrobial peptides from the venom of the eusocial bee Halictus sexcinctus (Hymenoptera: Halictidae) and their analogs. Amino Acids. 2010;39(3):763-75. 
29. Monincová L, Veverka V, Slaninová J, Budesínský M, Fucik V, Bednárová L, et al. Structure-activity study of macropin, a novel antimicrobial peptide from the venom of solitary bee Macropis fulvipes (Hymenoptera: Melittidae). J Pept Sci. 2014;20(6):375-84

30. Zalat S, Nabil Z, Hussein A, Rakha M. Biochemical and haematological studies of some solitary and social bee venoms. Egypt J Biol. 1999;1:57-71.

31. Hou C, Guo L, Wang J, You L, Lin J, Wu W, et al. Cloning and characterization of phospholipases A2 and hyaluronidase genes from the venom of the honeybee Apis mellifera carnica. Sociobiology. 2012;59(3):945-57.

32. Whelan S, Goldman N. A general empirical model of protein evolution derived from multiple protein families using a maximum-likelihood approach. Mol Biol Evol. 2001;18(5):691-9.

33. Kumar S, Stecher G, Tamura K. MEGA7: molecular evolutionary genetics analysis version 7.0 for bigger datasets. Mol Biol Evol. 2016;33(7):1870-4.

Submit your next manuscript to BioMed Central and we will help you at every step:

- We accept pre-submission inquiries

- Our selector tool helps you to find the most relevant journal

- We provide round the clock customer support

- Convenient online submission

- Thorough peer review

- Inclusion in PubMed and all major indexing services

- Maximum visibility for your research

Submit your manuscript at www.biomedcentral.com/submit
Biomed Central 